\title{
The Progress and Characteristics of Volunteer in National Parks
}

\author{
金 宣希* 油井 正昭** \\ Sun Hee KIM Masaaki YUI
}

\begin{abstract}
摘要 : 本研究は, 国立公園におけるボランティア制度の発展過程及びその特徵を明らかにし、ボラン ティア活動の方向性を検討するために行った。国立公園の利用者の増加により引き起こされた様々な 問題から最初のボランティアである自然公園指導員が 1957 年に委嘱され、1985 年にはPVが発足し, ボランティア活動が発展して来た。PV 活動は, 国立公園の管理官により活動の有効性が認められて おり, 満足度には活動の活発さ, 專用施設の整備, 研究会, 交流会, 管理官との意見交換などの影響 を受けることが明らかになった。
\end{abstract}

\section{1. 研究の背景と目的}

国立公園にお汸るボランティア制度の導入は，第２次世界大戦 後国民生活が次第に安定するにつれて, 国立公園の利用者が急増 したことが直接的なきっかけになっている。国立公園行政は, 1957 年にこのような利用者の増加に伴って多発する遭難事故や 自然破壊の防止・解決とともに自然保護思想の普及のため, 自然 公園指導員制度を設け, 国立公園管理へ国民の参加を得るボラン ティア制度をスタートさせた ${ }^{9 !}$ 。

社会・経済成長による利用者の増加 $\rightarrow$ 開発の促進 $\rightarrow$ 新しい利用 者の招来につながるメカニズムは，その結果として国立公園の保 護・管理の上で利用の安全性や自然破壊などの問題を発生させた が，現地における管理に対しては人手や予算が不足していて，問 題の円滑な解決が難しい状沉であった。そこで, 問題解決の一助 として国民の参加を得るボランティア活動が注目されることにな り，国民参加の方策も次第に発達して今日に至っている。

国立公園に打けるボランティアは, 無償で美化清掃, インター プリテーションなどに奉仕する民間人であり，現在は自然公園指 導員 (環境庁) をはじめ, パークボランティア (環境庁), 国立 公園サブレンジャー（(財)日本自然保護協会, 尾瀬保護財団派遣), 自然観察指導員 ((財) 日本自然保護協会), ビジターセンターボ ランティア（(財)日本自然保護協会等)など様々な形のボランティ アがある11。

ボランティアの定義は, (1)自発性(自主性), (2)無償性, (3)非営 利性，(4)継続性が原則とされる ${ }^{6)}$ 。しかし，国立公園で行われて いるボランティアのなかにはこの定義に合致しないものも存在す る。したがって, 国立公園行政で扱っているボランティアの定義 とは違いが見られる。

本研究では, 国立公園における管理の補助や利用者を対象に自 然への関心を誘導する手段として, 現実に行われているボランティ ア活動に着目して, 本研究が扱う国立公園におけるボランティア 定義としては，(1)無償の活動であること，(2)制度により国立公園 管理者側がボランティア活動を要請していることとした。

この条件を満たすのは自然公園指導員とパークボランティア （以下「PV」とする）であり，国立公園におけるボランティア 制度の発展過程を明らかにするとともに, PV 制度と PV 活動の 現状を把握し，その結果を踏まえて今後のPV 制度や活動の方 向性を検討することを目的とした。

\section{2. 研究の方法}

国立公園におけるボランティア制度の発展過程を明らかにする ために文献調查を行った。また, PV 活動の現状や特徴を把握す るために，アンケートを実施した。

アンケートでは, PV が活動している 23 国立公園 35 地区の管 理官（レンジャー）に対し, PV の導入年, PV 活動内容, PV 活動に重要な影響を与えると考えている活動検討会, 支援組織, 自治組織, PV 専用施設, 研修会, 機関誌の発行, PV 活動の有 効性, 活動に対する満足度などの設問を設け, 実態調查と意識調 査を並行した。アンケートは，2000 年 8 月上旬に郵送し， 9 月 下旬に 35 地区のうち 33 地区（94\%）から回答（回收率）を得た。

\section{3．国立公園におけるボランティア制度の発展}

国立公園のボランティア制度が始まった 1957 年以後のボラン ティア制度や活動に関する変遷を表一 1 に示した。

表 1 の中で制度に関しては, 自然公園指導員制度と PV 制度 の導入, ボランティア担当部署としての自然ふれあい推進室の設 置, 活動に関しては, 自然保護ボランティアファンドの支援活動 なよ゙がボランティア発展にとって重要事項と考えられ，これらの 事項を節目としてボランティアの発展過程を 3 期に区分した。

第 1 期は, 1957 年から 1984 年である。この時期は, 当時国立 公園行政を担当していた厚生省国立公園部において, 国立公園の 利用者指導, 自然保護思想の普及を目的に自然公園指導員制度が 設けられ，委嘱された自然公園指導員が現地で無給の活動を行っ た。誰でも自主的に参加できるものではないという点で完全なボ ランティアとはいえないが，これが国立公園に打けるボランティ ア活動の始まりである。自然公園指導員の活動が唯一であったこ の時期は，ボランティア活動の導入期といえる。

第 2 期は, 1985 年から 1992 年までである。この時期は自然公 園指導員の他に募集 (自発的に応募) によるボランティアである PV が発足し, 幅広く国民が参加できるボランティアの時代を迎 えた。そして, 自然保護ボランティア活動を支援するファンドが 設立され, 助成事業が始まった。国立公園行政を担当する環境庁 自然保護局には, ボランティア関連業務を担当する自然ふれあい 推進室が設置された。このように第 2 期は, ボランティア活動に 国民参加の機会が広がり，国立公園行政においては，ボランティ ア養成に必要な部署の設置を行うなど新たな展開があった。こう

*千葉大学大学院自然科学研究科 *千葉大学園芸学部 


\section{表ー 1 国立公園におけるボランティア制度及びボランティア活動の変遷}

\begin{tabular}{|c|c|c|}
\hline 区分 & 年度 & ボランティア制度・活動関連事項 \\
\hline \multirow{6}{*}{$\begin{array}{c}\text { 第 } \\
1 \\
\text { 期 }\end{array}$} & 1957 & 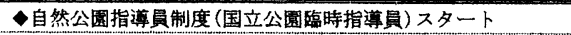 \\
\hline & 1966 & •国立公園臨時指導員から自然公園指導員へ名称变更 \\
\hline & 1968 & ↔自然公園指導賁設置要網を制定 \\
\hline & 1971 & 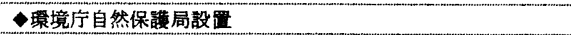 \\
\hline & 1974 & 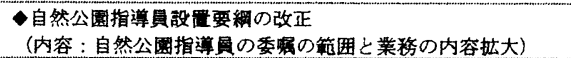 \\
\hline & 1979 & Q(財)自然公園美化管理財國発足 \\
\hline \multirow{6}{*}{$\begin{array}{l}\text { 第 } \\
2 \\
\text { 期 }\end{array}$} & 1985 & •自然保護教育活動推進事業開始(PV制度のスタート) \\
\hline & 1986 & ○公益信託自然保護ボランティアファンド設立 \\
\hline & 1987 & ○公益信託自然保護ボランティアファンドの助成事業閒始 \\
\hline & 1988 & •PV 活動基盤礊備事業スタート(目的：PV の養成) \\
\hline & 1991 & •環境庁自然保護局に自然ふれあい推進室設置 \\
\hline & 1992 & 15 国立公娄 19 地区にPV 導入 \\
\hline \multirow{7}{*}{$\begin{array}{c}\text { 第 } \\
3 \\
3 \\
\text { 期 }\end{array}$} & 1993 & -PV 強化事業(百的：PV活動の充実) \\
\hline & & •国立公堛 PV 設置要網を制定 \\
\hline & 1994 & 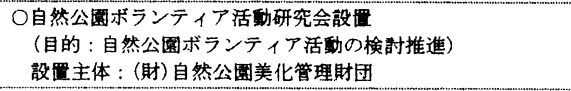 \\
\hline & 1996 & 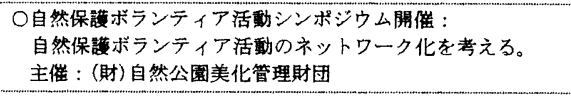 \\
\hline & 1997 & $\begin{array}{l}\text { O自然保講ボランティア活動ワークショップ開催： } \\
\text { コーディネーターのための保全活動のプログラムつくりと } \\
\text { 参加情報の提供を考える。主催：(財)自然公園美化管理財団 }\end{array}$ \\
\hline & 1998 & $\begin{array}{l}\text { O自然保護ボランティア活動シンポジウム開催： } \\
\text { 活動参加情報の地城的・国際的ネットワーク化を考える。 } \\
\text { 主催：(財)自然公囷美化管理財団 }\end{array}$ \\
\hline & 2000 & -23 国立公图 36 地区に PV 等入 \\
\hline
\end{tabular}

(凡例 : ↔ボランティア制度と関連する国の行政、○民間のボランティアフフンド活動)

した動向からボランティア活動に対する基盤がつくられ，自主的

に国民が参加できる制度によるボランティア普及の時期と捉える ことができる。

第 3 期は，1993 年以降である。環境庁は，PV 活動の充実を 目的に 1993 年に PV 強化事業をスタートした。また，1994 年に は，国立公園パークボランティア設置要綱を制定した。

民間の活動も活発になり，自然保護ボランティアファンドの協 力機関として助成事業の分担やボランティア活動の拠点施設を提 供している(財)自然公園美化管理財団は，ボランティア活動のネッ トワーク化やプログラム作成の充実を図るため，シンポジゥムや ワークショップを開催している。さらに，自然保護ボランティア ファンドの助成で, 自然公園ボランティア活動研究会を設置し ${ }^{8)}$, 2 年間ボランティア活動の充実を四るための検討を行った。パー クボランティア設置要綱の制定とともにボランティア活動の充実 に対する検討が行われており，上り活発な活動を行う努力が図ら れている。このような状況を踏まえ第 3 期は，ボランティア活動 の成長期として考えられる。

\section{4. 自然公園指導員制度}

第 2 次世界大戦後の国立公園は, 1970 年代前半まで利用者が 急増しつづけた。利用者の増加は，過剩利用や開発による自然破 壊の問題を引き起こした。また，この頃から国立公園の登山者の 激增による山岳遭難事故が社会の問題となった。

1953 年, 国立公園の現地管理のため, 国立公園管理員（レン ジャー）制度が始まり，この年採用された 6 人が現地に派遣され た が，国立公園で起こる様々な問題の解決には，人員が足りな かった。このような問題の解消を図るために，厚生省は，1957 年に「国立公園臨時指導員」を設けることとし，厚生省国立公園 部長名で，夏期は全日本山岳連盟加盟时体を中心に 119 人，冬期 はさらに全日本スケート連盟の参加を得て，200 余名を委嘱した。 国立公園臨時指導員は，現地において自然愛護，利用道徳，事故 防止を主な業務として活動しだ"1)。

その後, 国立公園臨時指導員は 1966 年に「自然公園指導員」 と名称を変更し, 自然公園利用者の指導の他に国立公園管理員事 表－２＼cjkstart国立公園における PV 制度の導入状況（1999 年 10 月現在）

\begin{tabular}{|c|c|c|c|}
\hline 国立公園名 & 実施地区名 & 現地実施年 & PV 人数 \\
\hline 釧路湿原 & 全域 & 1989 年 & 73 \\
\hline 知床 & 羅買 & 1987 年 & 40 \\
\hline \multirow[t]{2}{*}{ 阿寒 } & 摩周・届斜路 & 1989 年 & 43 \\
\hline & 阿寒湖畔 & 1994 年 & 25 \\
\hline 利居礼文サロベツ & 全域 & 1989 年 & 29 \\
\hline 大雪山 & 全域 & 1989年 & 138 \\
\hline 支笏洞挛 & 支笏湖 & 1991 年 & 54 \\
\hline \multirow{3}{*}{$\begin{array}{l}\text { 十和田 } \\
\text { 八幡平 }\end{array}$} & 十和田 & 1995 年 & 57 \\
\hline & 八幡平 & 1994 年 & 37 \\
\hline & 駒ヶ岳 & 1994 年 $\triangle$ & 31 \\
\hline 陸中海岸 & 宫古 & 1995 年 $\Delta$ & 19 \\
\hline \multirow[t]{2}{*}{ 日光 } & 日光 & 1987 年 $\triangle$ & 58 \\
\hline & 尾瀬 & 1985 年 & 47 \\
\hline \multirow[t]{2}{*}{ 磐梯朝日 } & 羽黒 & 1986 年 $\nabla$ & 35 \\
\hline & 裏磐梯 & 1990 年 $\triangle$ & 65 \\
\hline 富士箱根伊豆 & 箱根 & 1988 年 & 129 \\
\hline 中部山岳 & 上高地 & 1986 年 & 65 \\
\hline 上信越高原 & 妙高高原 & 1995 年 & 111 \\
\hline 白山 & 石川県域 & 1994 年 $\triangle$ & 83 \\
\hline 吉野熊野 & 大台ヶ原 & 1986 年 $\nabla$ & 103 \\
\hline 伊勢志魔 & 全域 & 1999 年 $\triangle$ & 32 \\
\hline 山陰海岸 & 竹野 & 1996 年 $\nabla$ & 60 \\
\hline \multirow{3}{*}{ 瀬戸内海 } & 會敖 & 1994 年 $\triangle$ & 46 \\
\hline & 五色台 & 1985 年 & 61 \\
\hline & 宮島 & 1999 年 & 44 \\
\hline 足摺宇和海 & 大月 & 1995 年 & 66 \\
\hline \multirow[t]{2}{*}{ 阿蘇くじゅう } & 阿蘇 & 1994 年 & 65 \\
\hline & くビ此 & 1985 年 $\boldsymbol{\nabla}$ & 44 \\
\hline \multirow[t]{2}{*}{ 雲仙天草 } & 雲仙 & 1989 年 & 39 \\
\hline & 天草 & 1989 年 & 60 \\
\hline \multirow{4}{*}{ 霧島屋久 } & 高千穂河原 & 1985 年 & 17 \\
\hline & えびの & 1985 年 & 67 \\
\hline & 指宿 & 1995 年 $\triangle$ & 17 \\
\hline & 屋久島 & 1996 年 & 45 \\
\hline 酉表 & 西表 & 1995 年 & 21 \\
\hline 23 国立公園 & 35 地区 & \multicolumn{2}{|c|}{1,808 人 } \\
\hline
\end{tabular}

務所への情報提供が活動に加えられた。1974 年には，スキー， 水泳の指導員や公園内または付近に居住し，公園の実状に詳しい 人などへ委嘱の対象を広げ，現在の「自然公園指導員」の形態が 整えられた 嘱されている。

1997 年現在，3,067 人の自然公園指導員が全国の国立・国定公 園で活動している。そのうち国立公園の自然公園指導員は，都道 府県からの推樜 1,613 人, (財)国立公園協会からの推薦 250 人, 合計 1,863 人である7 。任期は 2 年間で，初任者にはブロック別 の研修会が年 $3 \sim 4$ 回実施されている。自然公園指導員は，保険 が国費で支援される以外は無給の活動であり，国立公園の管理に 一般の国民が無給で参加する最初の制度と位置付けできる。しか し, 自然公園指導員制度は, 自発的参加ではない点で完全なボラ ンティア活動とはなっていないといえる。

5。 パークボランティア制度

\section{(1) PV 制度の実施現況}

PVは1985 年に環境广丁自然保護教育活動推進事業の 1 種之 して取り上げられた。初年は 4 地区をモデルとしてスタートし ${ }^{3)}$, 1999 年現在, 23 国立公園 35 地区で導入されている。PV は各地 区毎に登録制となっており，環境庁自然ふれあい推進室が公表し ている資料によると， 35 地区で合計 1,808 人が登録している 表一 2 は，PV制度の導入年と登録人数を示したものである。 PV 活動の開始年については, 環境庁が把握している年と現地の アンケートで調べた年が一致していない地区がある。このような 
表ー３＼cjkstart国立公園におけるパークボランティア現状（1999 年現在）

\begin{tabular}{|c|c|c|c|c|c|c|c|c|c|c|c|c|c|c|c|c|c|c|}
\hline \multirow{2}{*}{ 国立公園名 } & \multirow{2}{*}{ 実施地区名 } & \multicolumn{10}{|c|}{ I. PV 活動内容 } & \multicolumn{7}{|c|}{ II. PV の組織・施設整備状況 } \\
\hline & & $\begin{array}{l}\text { 美 } \\
\text { 化 } \\
\text { 清 } \\
\text { 掃 }\end{array}$ & $\begin{array}{l}\text { 自 } \\
\text { 然 } \\
\text { 解 } \\
\text { 説 } \\
\text { 案 } \\
\text { 内 }\end{array}$ & $\begin{array}{l}\text { 自 } \\
\text { 然 } \\
\text { 情 } \\
\text { 報 } \\
\text { 収 } \\
\text { 集 }\end{array}$ & $\begin{array}{l}\text { 講ラ } \\
\text { 演イ } \\
\text { 会ド } \\
\text { 及上 } \\
\text { さ映 } \\
\text { ス会 }\end{array}$ & $\begin{array}{l}\text { 地 } \\
\text { 域勉 } \\
\text { 文強 } \\
\text { 化会 } \\
\text { 紹 } \\
\text { 介 }\end{array}$ & $\begin{array}{l}\text { 自 } \\
\text { 然 } \\
\text { 環 } \\
\text { 境 } \\
\text { 調 } \\
\text { 查 }\end{array}$ & $\begin{array}{l}\text { 自 } \\
\text { 然 } \\
\text { 復 } \\
\text { 元 }\end{array}$ & $\begin{array}{l}P V \\
\text { 機 } \\
\text { 関 } \\
\text { 誌 } \\
\text { 作 } \\
\text { 成 }\end{array}$ & $\begin{array}{l}1 \\
\stackrel{1}{*} \\
2 \\
1 \\
\text { 補 } \\
\text { 助 }\end{array}$ & $\begin{array}{l}z \\
\sigma \\
\text { 他 }\end{array}$ & $\begin{array}{l}\text { 支 } \\
\text { 援 } \\
\text { 組 } \\
\text { 織 }\end{array}$ & $\begin{array}{l}\text { 自 } \\
\text { 治 } \\
\text { 組 } \\
\text { 織 }\end{array}$ & $\begin{array}{l}\text { 專 } \\
\text { 用 } \\
\text { 施 } \\
\text { 設 }\end{array}$ & $\begin{array}{l}\text { 娭 } \\
\text { 討 } \\
\text { 会 }\end{array}$ & $\begin{array}{l}\text { 交 } \\
\text { 流 } \\
\text { 会 }\end{array}$ & $\begin{array}{l} \\
\text { 研 } \\
\text { 修 } \\
\text { 会 }\end{array}$ & $\begin{array}{l}\text { 機 } \\
\text { 関 } \\
\text { 誌 }\end{array}$ \\
\hline 釧路湿原 & 全域 & e & - & - & & 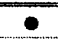 & & & - & - & & & - & & - & & 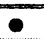 & - \\
\hline 知床 & 羅田 & 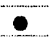 & - & 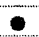 & & & e & & $\bullet$ & e & & & 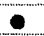 & & & $\bullet$ & & $\bullet$ \\
\hline \multirow[t]{2}{*}{ 阿寒 } & 摩周・屈斜路 & e & - & 0 & e & & 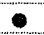 & & & & & & 0 & & 0 & 6 & $\bullet$ & 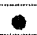 \\
\hline & 阿寒湖畔 & e & $\bullet$ & $e$ & & e & 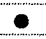 & & $\bullet$ & & & - & & & & $\bullet$ & & $\bullet$ \\
\hline 利尻礼文 & 全域 & - & $\bullet$ & & $\bullet$ & & & & $\bullet$ & - & & - & & & & & - & $\bullet$ \\
\hline 大雪山 & 全域 & - & $\bullet$ & - & - & & - & & - & - & & $\bullet$ & $\bullet$ & $\bullet$ & $\bullet$ & $\bullet$ & $\bullet$ & $\bullet$ \\
\hline 支䇗洞莭 & 支筇湖 & - & - & - & & & & & $\bullet$ & $\bullet$ & & & & & $\bullet$ & & - & $\bullet$ \\
\hline \multirow[t]{3}{*}{ 十和田八蟠平 } & 十和田 & - & $\bullet$ & $\bullet$ & & & & 6 & $\bullet$ & $\bullet$ & & & - & & $\bullet$ & $\bullet$ & $\bullet$ & 6 \\
\hline & 八幡平 & - & - & & & & & $\bullet$ & - & $\bullet$ & - & & $\bullet$ & & $\bullet$ & - & - & $\bullet$ \\
\hline & 南八幡平 & $\bullet$ & $\bullet$ & & & & & & $\bullet$ & $\bullet$ & - & & e & $\bullet$ & - & $\bullet$ & 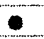 & $\bullet$ \\
\hline 陸中海岸 & 宮古 & - & - & & & & & & & & & $\bullet$ & $\bullet$ & $\bullet$ & $\bullet$ & $\bullet$ & - & $\bullet$ \\
\hline \multirow[t]{2}{*}{ 日光 } & 日光 & - & $\bullet$ & $\bullet$ & & & $\bullet$ & $\bullet$ & $\bullet$ & - & & $\bullet$ & - & $\bullet$ & - & - & - & $\bullet$ \\
\hline & 尾瀬 & & & & & & & & & & & & & & & & & \\
\hline \multirow[t]{2}{*}{ 般梯朝日 } & 羽黒 & $\bullet$ & - & $\bullet$ & & 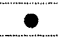 & & $\bullet$ & & - & & $\bullet$ & & - & $\bullet$ & $\bullet$ & $\bullet$ & $\triangle$ \\
\hline & 婁磐梯 & - & $\bullet$ & - & e & $\bullet$ & - & & e & $\bullet$ & e & $\bullet$ & 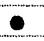 & & $\bullet$ & $\bullet$ & e & $\bullet$ \\
\hline 富士箱根伊豆 & 箱根 & $\bullet$ & $\bullet$ & $\bullet$ & & & & & $\bullet$ & $\bullet$ & $\bullet$ & $\bullet$ & $e$ & e & $e$ & $\bullet$ & $\bullet$ & $\bullet$ \\
\hline 中部山医 & 上高地 & $\bullet$ & $\bullet$ & & & & - & & - & & $\bullet$ & & - & $\bullet$ & $\bullet$ & $\bullet$ & - & $\bullet$ \\
\hline 上信越高原 & 怒高高原 & - & $\bullet$ & & & & & & - & & & - & & $\bullet$ & $\bullet$ & - & $\bullet$ & $\bullet$ \\
\hline 白山 & 石川県域 & & $\bullet$ & 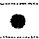 & - & - & & & & & & $\bullet$ & $\bullet$ & - & $\bullet$ & - & - & - \\
\hline 吉野熊野 & 大台々愿 & 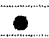 & $\bullet$ & - & $\bullet$ & & 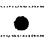 & e & & $\bullet$ & - & - & & $\bullet$ & & & $e$ & $\bullet$ \\
\hline 伊知志摩 & 全域 & $\bullet$ & $\bullet$ & & & & & & - & - & & & - & & $\bullet$ & & & $\bullet$ \\
\hline 山隐海岸 & 竹野 & $\bullet$ & $\bullet$ & 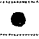 & & & - & & & $\bullet$ & & - & & - & $\bullet$ & & $\bullet$ & \\
\hline \multirow{3}{*}{ 瀬户内海 } & 含數 & $\bullet$ & $\bullet$ & & & & & e & & & & & & 0 & $\bullet$ & & & $\bullet$ \\
\hline & 五色台 & & $\bullet$ & 0 & & & & $\bullet$ & $\bullet$ & $\bullet$ & & & & $\Delta$ & $\bullet$ & & & $\bullet$ \\
\hline & 黨皇 & $\bullet$ & & & & & & & & $\bullet$ & & & $\bullet$ & & $\bullet$ & & $\bullet$ & $\Delta$ \\
\hline 足摺宇和海 & 大月 & - & $\bullet$ & $\bullet$ & $\bullet$ & & - & $\bullet$ & - & $\bullet$ & & $\bullet$ & $\bullet$ & $\bullet$ & - & $\bullet$ & $\bullet$ & $\bullet$ \\
\hline \multirow[t]{2}{*}{ 阿蘇くじゅう } & 阿蘇 & 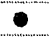 & 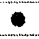 & - & & & & $\bullet$ & & - & & & & & - & - & $\bullet$ & $\bullet$ \\
\hline & $<E$ & - & $\bullet$ & & & & - & & $\bullet$ & & & & e & & e & $\bullet$ & 6 & - \\
\hline \multirow[t]{2}{*}{ 雲仙天草 } & 雲仙 & - & - & 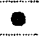 & & & & $\bullet$ & $\bullet$ & - & & $\bullet$ & - & & - & & $\bullet$ & $\bullet$ \\
\hline & 天草 & $\bullet$ & $\bullet$ & $\bullet$ & & & - & $\bullet$ & $\bullet$ & $\bullet$ & & & 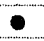 & $\bullet$ & 0 & 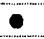 & $e$ & $\bullet$ \\
\hline \multirow[t]{4}{*}{ 籍泉屋久 } & 高千穂河原 & - & $\bullet$ & $\bullet$ & & - & & & & $\bullet$ & & & & & $\bullet$ & $\bullet$ & - & \\
\hline & えびの & $\bullet$ & $\bullet$ & $\bullet$ & $\bullet$ & - & & & - & $\bullet$ & $\bullet$ & & & $\bullet$ & $\bullet$ & $\bullet$ & $\bullet$ & \\
\hline & 指宿 & $\bullet$ & $\bullet$ & & & $\bullet$ & & & & $\bullet$ & & - & - & & - & & & \\
\hline & 屋久禹 & $\bullet$ & & $\bullet$ & & & & & - & & $\bullet$ & & 6 & $\bullet$ & $\bullet$ & $\bullet$ & - & $\bullet$ \\
\hline 西表 & 西表 & $\bullet$ & $\bullet$ & $\bullet$ & & & & & & - & & & - & & $\bullet$ & & $\bullet$ & \\
\hline 23 国立公園 & 35 地区 & 32 & 32 & 23 & 8 & 8 & 12 & 11 & 22 & 25 & 8 & 15 & 22 & 16 & 30 & 22 & 28 & 27 \\
\hline
\end{tabular}

ずれは，13 地区で見られる。その状況は表 2 のなかに $\triangle \boldsymbol{\nabla}$ 印で

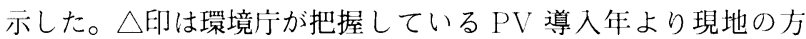
が早い地区を示し，印は環境宁が把握している PV 導入年よ り現地の活動開始が遅い地区を示している。このずれは(1)環境庁 で制度適用を決めてから，準備などで現地の活動開始が遅れた地 区（PV 登録に先立ち実務経験期間や研修を経て正式の活動を認 める)，(2)現地のボランティア活動が環境庁の制度より以前から 行われていた地区があるなどによって生じたものと考えられる。

PV 登録人数は, 100 人以上の地区が大雪山, 箱根, 妙高高原, 大台ヶ原の 4 地区，50人以下の小規模地区が 19 地区である。

(2) PV 活動の内容

PV は, 自然解説, 美化清掃, 公園施設の維持・管理などの保 護管理業務や利用指導に協力する目的で導入され, 地区毎に様々 な活動を行っている。活動内容については, 日光と箱根の PV 活動の研究を参考に 10 項目設定して調査を実施し, その結果 を表一 3 に各地区別のPV 活動として示した。

表一 3 から PV 活動の傾向を見ると, 維持・管理活動として 美化清掃が最も盛んで 35 地区中 32 地区（86\%）であり, 利用者 へのサービス活動である自然観察会（自然解説）も32地区 （86\%）で実施されおり，活発であった。自然情報収集活動（23 地区）やイベントの補助活動（25地区）屯多くの地区で行われ ている。これに対し講演会や勉強会などは一部地区に限って行わ れる傾向が見られた。その他の活動は, 施設の整備や補修, 利用
者指導なよ゙を行っていた。

地区別では, 裹磐梯, 大台ヶ原, 大月, えびの地区が $8 \sim 9$ 種 の幅広い活動を行っている。以下 7 種が 3 地区, 6 種が 8 地区, 5 種が 9 地区， 4 種が 6 地区， 3 種以下は 4 地区となっている。 5〜6種の活動が行っている地区が最も多いことが分かった。宮 古, 宮島, 妙高高原, 倉敷の 4 地区は, $2 \sim 3$ 種の活動に絞って 活動を行っている。

（3）公益信託自然保護ボランティアファンドの支援

PV 活動は, 各地区每に登録制となっており, 各地区で地元が PV 活動を支援している場合が多いが, 自然保護ボランティアファ ンドからも多大な活動支援を受けている。

公益信託自然保護ボランティアファンドは, 緑を增やし明るい 社会環境作りを目的に設立された(財)ゴルファーの緑化促進協力 会の協力により1986 年に設立されたものであり, 1987 年から助 成事業を開始している。（財)ゴルファーの緑化促進協力会が設定 した基金に個人，法人，団体の寄付金など募金型公益信託を合わ せて三井信託銀行が受託し, 自然保護に関するボランティア活動 に対して助成事業を行っている ${ }^{12)}$ 。国立公園のPV 活動に対し ては, (1)公園内の美化清掃活動, (2)高山植物などの盗掘防止パト ロール活動, (3)高山植生などの復元活動, (4)野生生物を守り育て る活動, (5)公園利用者への自然解説, 利用者指導活動, (6)公園施 設の維持, 補修活動に助成を行っている。

PV 活動に対する自然保護ボランティアファンドからの助成状 
況は，表一 4 のとおりである。

自然保護ボランティアファンドが助成を開始した 1987 年から 1996 年までの 10 年間に 24 国立公園内の 34 地区で 51 団体が助 成を受けた。表一 4 から PVが組織されている35 地区のなかで は日光国立公園の尾瀬地区之瀬戸内海国立公園の宮島地区の 2 地 区が助成を受けていない。助成金額は総額 5,760 万円を支援し た ${ }^{5)}$ 。

地区別では, 妙高高原之上高地が他の地区に比較して助成を受 けた実績が高い。妙高高原の場合は, 1988 年から 1996 年まで毎 年欠かさず助成を受けているが, 助成を受けているのは, 全て PV 組織とは別の団体であり, また上高地の場合も 10 年間に 15 回の助成を受けているうちの 10 回はPV 組織ではない団体であ り, PV 組織の助成は 5 回となっている。この 2 地区以外では, 箱根 ( 7 回), 日光 (6 回), 摩周・屈斜路 ( 6 回) が 助成を受 けた回数の多い地区になっている。

\section{6. 国立公園管理官（レンジャー）に対するアンケート結果 (1) PV 活動の地区別現状}

PV 活動に影響を与えると考えられる支援組織, 自治組織, PV 専用施設, 検討会, 交流会, 研修会, 機関誌の 7 項目に対し て国立公園管理官（以下「管理官」という）加得た回答を整理 し, 各地区の現況を表一 3 に示した。

PV に対して地元を中心に, 経済的支援やイベントなどでの地 域住民の協力活動を行っている支援組織は 15 地区, PV が円滑 な活動を推進して行くために発足した自治組織は, 22 地区に設 置されている。自治組織の必要性に関する管理官の意識は図一1 に見るとおりで，23 地区（72\%）の管理官が「とても必要」と 「やや必要」の必要性を回答している。「やや不必要」と「全く不 必要」が 9 名いるが, 自治組織が円滑な活動を推進することを目 的にするなら，設置した方がよいのではないかと思われる。

専用施設については，25 地区（78\%）の管理官が必要性を認 め(図-1), 専用施設が整備されていない地区での期待も高い ことが明らかになった。

活動プログラムの作成や PV 活動の月・年間計画を検討する 検討会は 30 地区で行っている。PV 活動のための基本教育や知 識を修得する研修会は, 35 地区のうち 28 地区で行われている。

他地区との交流会は, 22 地区で実施されているが, 全てが不 定期で行っていた。交流会は, 地区活動の紹介, 意見交換による 親睦を図るのが目的であるが, 今後は PVのネットワークへの 役割が期待され, 交流会の開催は 27 地区（82\%）の管理官が必 要性を認めている（図-1）。

PV の機関誌は, PV 間の連絡, 活動報告, 活動予定などを知 らせる重要な情報誌といえるが, 全国 27 地区で発行されており, そのうち 25 地区は定期的に発行している。年間の発行回数は 4 〜 5 回が 10 地区と最も多く, $1 \sim 3$ 回が 8 地区, $11 \sim 12$ 回が 6 地区であった。年間 11 12 回の発行は, 毎月 1 回の発行に相当 するので, 編集・発行業務が大変と思われるが, 22 地区がこの機

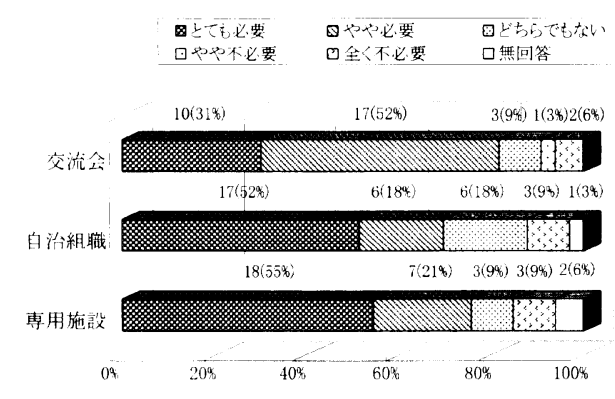

図-1 交流会, 自治組織, 専用施設の必要性
関誌の発行業務をPV 活動の中心において熱心に取り組んでいる。 支援組織, 自治組織, PV 専用施設, 検討会, 交流会, 研修会, 機関誌の 7 項目の現況調查から大雪山, 宮古, 日光, 箱根, 大月 の 5 地区は, 全ての項目で該当しており, 整備が進んでいる地区 であるといえる。

\section{（2） PV 募集及び活動についての管理官の意識}

PV 活動が国立公園管理に有効であるか否かを問いかけた結果, 管理官の評価は, 「とても有効」が 13 地区（39\%)，「やや有効」 が 17 地区 (52\%) であり, PV 活動は国立公園管理に有効に寄 与していることが明らかになった（図一2）。

各地区において管理官と PV とのコミュニケーションについ ては，28 地区（85\%）から意見交換などコミュニケーションの 機会があることが回答された。これに対し「あまりない」が 4 地 区 (12\%)，「全くない」は1地区（3％)であった。

PV 活動の活発さに関しては, 図一2に見るように「あまり活 発ではない」,「全く活発ではない」という回答が 16 地区あり, 35 地区の半数地区の管理官が活動は活発ではないと見ている。 活動の活性化を妨げている問題としては, PV の募集に年齢制限 があることや登録しても活動していないPVの存在などが考え られる 期的募集について調査した結果を図一 3 に示した。

現行 PV 制度は，年齢制限が設けられているが，この年齢制 限については，「不必要」という回答が 22 地区（67\%）で最も多 い。このことは活動への意志があれば，年齢に関係なく，参加の 機会を与えることが必要であると考えられていることを示している。

登録しても活動しないPVについては，21 地区（64\%）で資 格制限を行う必要があるとの回答を得た。資格制限に関しては, ボランティア活動であることを勘案し，制限を行う前に参加しな い原因の把握や自発的に参加できる方法を検討することも重要で, 資格制限は最後の手段とすることが望ましい。資格制限を設ける には，地区毎にPV 活動の実施要綱を設け，年間の活動回数や PV 認定期間を明確に提示することも検討が必要と考える。

定期的募集の必要性については,「必要」と「不必要」の回答 が両者とも 13 地区（39\%）と同数だった。定期的募集を必要で ないとする意見では，登録人数か増え，PVの管理がうまくでき ない場合, 新しい問題が起こるおそれがあるとの指摘があった。

PV 活動の報告や連絡の役割を持つ機関誌の充実度については, 19 地区（58\%）が充実していると回答している（図-4）。

(3) PV 活動の満足度と各項目の相関関係

$\mathrm{PV}$ 活動の満足度（図一-4）を求めた結果, 「とても満足」と 「やや満足」の合計が 19 地区（58\%）上なった。しかし，「とて も不満足」と「やや不満足」が 9 地区（27\%）あり，管理官が期 待している程は活動できていない地区が，全地区の $1 / 3$ 近くも 存在していることが把握された。この満足度に影響を与えている 要素を把握するために満足度と各項目との相関分析を行い, 結果 を表一 5 に示した。

満足度と関連性が見られた項目は 5 項目あり, 交流会, 活動の

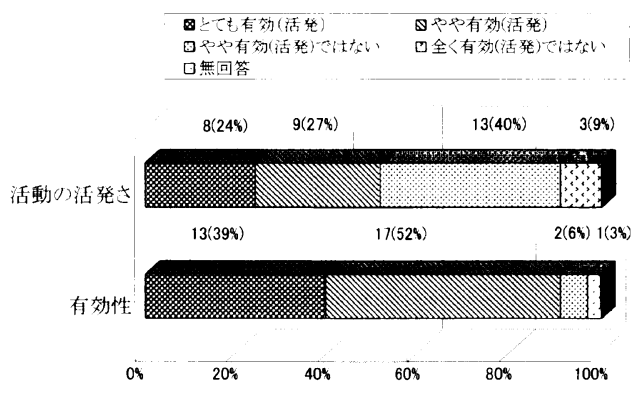

図－２＼cjkstart国立公園管理における PV 活動の有効性 


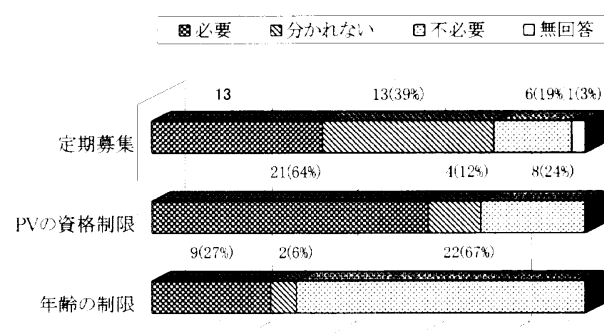

図-3 年齢・活動しないPVの資格制限と定期募集の必要性

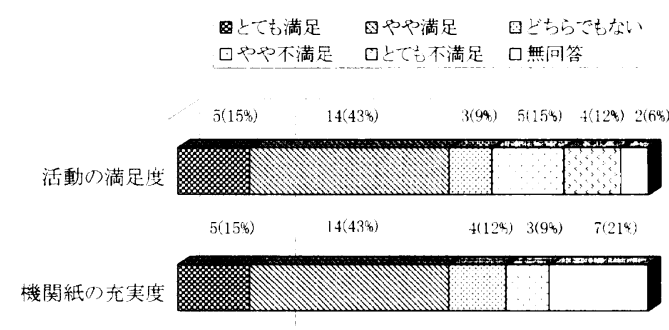

$08 \quad 20 \% \quad 40 \% \quad 60 \% \quad 80 \% \quad 100 \%$

図-4 活動の満足度と機関誌の充実度

表 -4 国立公園地区別公益信託自然保護ボランティアファンドの助成

\begin{tabular}{|c|c|c|c|c|c|c|c|c|c|c|c|c|c|}
\hline 国立公園名 & 寒施地区名 & 87 年 & 88 年 & 89 年 & 90 年 & 91 年 & 92 年 & 93 年 & 94 年 & 95 年 & 96 年 & 総計 & 団体数 \\
\hline 鉤路湿原 & 金域 & & (1) & (1) & & (1) & & (1) & & & (1) & (5) & (1) \\
\hline 知床 & 羅白 & 1 & & 1 & 1 & 1 & & & & & & 4 & 1 \\
\hline \multirow[t]{2}{*}{ 阿寒 } & 魔周・屈斜路 & & & & 1 & 1 & 1 & & 1 & 1 & 1 & 6 & 1 \\
\hline & 阿寒湖畔 & & & & & & & & & 1 & 1 & 2 & 1 \\
\hline 利完礼文サロベッ & 全域 & & 1 & & 1 & 1 & & & & & & 3 & 1 \\
\hline 大雪山 & 全域 & & & 1 & & & 1 & & & & 1 & 3 & 2 \\
\hline 圭篎洞爺 & 支笏湖 & & & & & 1 & 1 & $1(1)$ & (1) & $1(1)$ & 1 & $5(3)$ & 2 \\
\hline \multirow{3}{*}{$\begin{array}{l}\text { 十和田 } \\
\text { 八幡平 }\end{array}$} & 十和田 & & & & & & & & & 1 & 1 & 2 & 1 \\
\hline & 八蟠平 & & & 1 & & & 1 & 1 & & (1) & (1) & $3(2)$ & $1(1)$ \\
\hline & 南八幡平 & & & & 1 & & & & & & & 1 & 1 \\
\hline 陸中海崖 & 宮古 & & & & & 1 & 1 & & & & & 2 & 1 \\
\hline \multirow[t]{2}{*}{ 日光 } & 日光 & 1 & & 1 & 1 & 1 & & & 1 & & 1 & 6 & 1 \\
\hline & 尾瀬 & & & & & & & & & & & & 0 \\
\hline \multirow[t]{2}{*}{ 整梯朝日 } & 羽黑 & & & & & 1 & 1 & 1 & & & & 3 & 1 \\
\hline & 寒盤梯 & & & & 1 & 1 & 1 & & 1 & 1 & & 5 & 1 \\
\hline 富士箱根伊豆 & 箱根 & & 1 & 1 & 1 & & 1 & 1 & 1 & & 1 & 7 & 1 \\
\hline 中部山岳 & 上高地 & 1 & & (2) & (1) & (1) & $1(1)$ & $1(2)$ & $1(2)$ & $1(1)$ & & $5(10)$ & $1(4)$ \\
\hline 上信越高原 & 妙高高原 & & (3) & (2) & (1) & (1) & (2) & (2) & (2) & (3) & (3) & (19) & (9) \\
\hline 白篮 & 䂦膊域 & & & & & 1 & 1 & 1 & 1 & & & 4 & 1 \\
\hline 吉野熊野 & 大台为 & 1 & 1 & 1 & & 1 & & & 1 & & & 5 & 1 \\
\hline 伊茒志摩 & 全域 & & & & & & 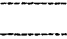 & 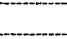 & & & (1) & (1) & (1) \\
\hline 山陸海崖 & 价野 & & & & & & 1 & 1 & 1 & 1 & & 4 & 1 \\
\hline \multirow[t]{3}{*}{ 瀬戸内海 } & 倉敫 & & & & & & 1 & 1 & 1 & & & 3 & 1 \\
\hline & 五色台 & (1) & (1) & & & & & & & & & (2) & (1) \\
\hline & 宮岛 & & & & & & & & & & & & 0 \\
\hline 足摺宇和海 & 大月 & & & & & & & & & & 1 & 1 & 1 \\
\hline 大山䧟吱 & 三瓶山 & & & (1) & (1) & & & & & & & (2) & (1) \\
\hline \multirow{2}{*}{$\begin{array}{l}\text { 阿藟 } \\
\text { くじゅう }\end{array}$} & 阿蘇 & & (1) & & & & & 1 & 1 & 1 & & $3(1)$ & $1(1)$ \\
\hline & $\leq 462$ & (1) & (1) & & (1) & & & & & & & (3) & 1 \\
\hline \multirow[t]{2}{*}{ 雲仙天草 } & 䨐仙 & & & & 1 & & 1 & & & 1 & 1 & 4 & 1 \\
\hline & 天草 & & & & & & & (1) & (1) & & & (2) & 1 \\
\hline \multirow[t]{4}{*}{ 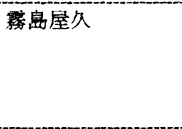 } & 高千穗河原 & & & 1 & 1 & 1 & 1 & & & & & 4 & 1 \\
\hline & えびの & & 1 & 1 & 1 & & & & & & & 3 & 1 \\
\hline & 指宿 & & & & & & & & & 1 & & 1 & 1 \\
\hline & 軖久島 & & & & & & & & & & 1 & 1 & 1 \\
\hline 西表 & 西表 & & & & (1) & (1) & & & & 1 & & $1(2)$ & $1(1)$ \\
\hline \multirow[t]{2}{*}{24 国立公園 } & \multirow[t]{2}{*}{36 地区 } & $\begin{array}{c}4 \\
(2)\end{array}$ & $\begin{array}{c}4 \\
(7) \\
\end{array}$ & $\begin{array}{c}8 \\
(6)\end{array}$ & $\begin{array}{l}10 \\
(5)\end{array}$ & $\begin{array}{l}10 \\
(5)\end{array}$ & $\begin{array}{c}12 \\
(5)\end{array}$ & $\begin{array}{c}7 \\
(9)\end{array}$ & $\begin{array}{c}8 \\
(8)\end{array}$ & $\begin{array}{c}10 \\
(7)\end{array}$ & $\begin{array}{c}10 \\
(6)\end{array}$ & $\begin{array}{c}85 \\
(58)\end{array}$ & $\begin{array}{c}31 \\
(20)\end{array}$ \\
\hline & & 6 & 11 & 14 & 15 & 15 & 17 & 16 & 16 & 17 & 16 & 143 & 51 \\
\hline
\end{tabular}

※（）住PV 以外の団体数

表 $-5 \quad \mathrm{PV}$ 活動の満足度と各項目の相関関係

\begin{tabular}{|c|c|c|c|c|c|c|c|c|c|c|c|c|c|c|}
\hline 項目 & 满足度 & 有効性 & 㭘討会 & 交流会 & 研修会 & $\begin{array}{l}\text { 支授 } \\
\text { 組䋨 }\end{array}$ & $\begin{array}{l}\text { 自治 } \\
\text { 組織 }\end{array}$ & $\begin{array}{l}\text { 專用 } \\
\text { 施設 }\end{array}$ & 活発さ & $\begin{array}{l}\text { 意見 } \\
\text { 交換 }\end{array}$ & $\begin{array}{l}\text { 機関誌 } \\
\text { 充実度 }\end{array}$ & $\begin{array}{l}\text { 年酷 } \\
\text { 制限 }\end{array}$ & $\begin{array}{l}\text { 资格 } \\
\text { 制限 }\end{array}$ & $\begin{array}{l}\text { 定期 } \\
\text { 基集 }\end{array}$ \\
\hline 满足度 & 1.000 & & & & & & & & & & & & & \\
\hline 有効性 & $.631 *$ & 1. 000 & & & & & & & & & & & & \\
\hline 㭘討会 & -.005 & -.256 & 1.000 & & & & & & & & & & & \\
\hline 交流会 & $.363 * *$ & .22 & -199 & 1000 & & & & & & & & & & \\
\hline 研修会 & .326 & $.541 * *$ & -.066 & .297 & 1.000 & & & & & & & & & \\
\hline 支援組織 & .396 & .173 & .346 & -.140 & -.069 & 1.000 & & & & & & & & \\
\hline 自治組織 & .116 & .158 & .079 & .203 & .102 & -.163 & 1.000 & & & & & & & \\
\hline 専用施設 & $.376 *$ & .399 & .097 & .267 & .246 & -.138 & .061 & 1.000 & & & & & & \\
\hline 活動の活発さ & $.718 * *$ & $661 * *$ & $-.365 *$ & $.535 * *$ & $.417 *$ & .159 & .175 & .173 & 1.000 & & & & & \\
\hline 意見交換 & $.507 * *$ & $.509 * *$ & -.147 & .29 & .307 & .324 & -.066 & .072 & $.634 * *$ & 1. 000 & & & & \\
\hline 機閉誌克赛度 & .200 & $.408 *$ & -.175 & -.146 & .227 & -.019 & .200 & .099 & .344 & .141 & 1.000 & & & \\
\hline 年齢制限 & .068 & .009 & $-415 *$ & .064 & .106 & $\because .266$ & .008 & .232 & .000 & .071 & .364 & .1 .000 & & \\
\hline 资格制限 & .304 & .212 & .005 & .163 & .102 & .090 &. .292 & .019 & .244 & -.150 & .198 & .112 & 1.000 & \\
\hline 定期塞集 & .172 & .325 & $-.422 *$ & .303 & .011 & .061 & .083 & .080 & .276 & .275 & -.087 & .114 & -.043 & 1.000 \\
\hline
\end{tabular}

数字: Pearson 相関係数、**: Correlation is significant at
$*$ : Correlation is significant at the 0.05 level (2-tailed) 
活発さ, 管理官との意見交換の 3 項目は有意性 1\%水準の高い関 連性を示した。PV 活動の有効性と PV 専用施設の整備の 2 項目 は $5 \%$ 水準の有意性があった。満足度と高い関連性が見られた活 動の活発さは, 検討会, PV 活動の有効性, 交流会, 研修会, 管 理官と意見交換の 5 項目と関連していることが把握された。なお, PV 活動の有効性は機関誌の充実度, 研修会, 活動の活発さ, 管 理官と意見交換との間で有意性が見られた。

専用施設, 組織の整備が良好な地区が活動の盛んな地区であっ たが，専用施設，組織の整備が良好な地区であってもあまり活動 が活発ではない地区があるので，相関分析をもとに，管理官が PV 活動に不満を思っている要素を調べた結果，「やや不満」な いしは,「とても不満」を回答した 9 地区全てが活動人数 50 人以 下の地区（20人以下：2地区，21-30人：3 地区，31-50人：4 地区）であった。このことをふまえると, 小人数では活動も限定 されるであろうし, 活発な活動が行いにくいという実態があるの ではないかと考えられた。

\section{8.まとめ}

\section{（1）国立公園管理におけるボランティア活動の有効性}

現在, 国立公園のボランティア活動の中心になっている PV 活動が国立公園の管理に有郊な活動であるかを調査した結果，90 \%以上の管理官が PV 活動の有効性を認め，ボランティア活動 が有効であることが明確になった。

\section{（2）国立公園におけるボランティア活動の発展過程}

国立公園の利用者の増加により引き起こされた様々な問題から 始まった国立公園のボランティア活動は，国立公園行政の变革之之 あに変わって来た。今日までの発展経過は 3 つの時期に分けられる。

第 1 期（1957 年〜1984 年）は，自然公園指導員が中心のボラ ンティア活動であり，自然公園指導員が委嘱制であるため，完全 なボランティアとはいえないが，国立公園にボランティア活動が 制度的に導入された導入期といえる。

第 2 期（1985 年〜1992 年）は，募集によるボランティア活動 が発足し，国民が自発的に参加できるボランティア活動の広がっ た普及期であった。環境庁自然保護局の組織改革で PV に関す る業務を担当する自然ふれあい推進室が設置され，以前より組織 的・体系的ボランティア活動が展開されるようになった。

第 3 期（1993 年〜現在）は, PV 活動の充実を目的に環境宁 のPV 強化事業（1993 年）がスタートし，（財）自然公園美化管 理財団がボランティア活動のネットワーク化やプログラムの作成 とともに自然公園ボランティア活動研究会を設置し，自然公園に
おけるボランティア活動の充実に向けて研究を進めて来た。した がって，この時期はボランティア活動の成長期として考えられる。 （3）ボランティア活動の内容及びその特徵

自然公園指導員は 40 年以上の歴史を屯っており，時代の変遷 とともに活動の内容が自然保護思想の普及・事故の予防から利用 者指導や利用者サービスの業務が強化されて来た。自然公園指導 員制度は，現在 28 国立公園全てに対して実施されていて，最も 歴史を有し人員の多い制度である。

PV は活発な活動が注目されるが，様々な活動のうち美化清掃 (公園維持・管理)，自然解説（利用者サービス）が最も盛んな活 動として把握された。

調查結果から大雪山, 宮古, 日光, 箱根, 大月の 5 地区は, PV 活動のため, 専用施設や組織の整備が最も良好な地区であった。

なお，PVは公益信託自然保護ボランティアファンドから多大 な支援を受けている。

専用施設, 組織, 助成金, 活動の活発さ，活動の満足度など様々 な項目から PV 活動を見ると，専用施設や組織が整備され，助 成を繰返し受けている地区が活動も盛んであり，この結果，35 地区の中で大雪山, 日光, 箱根の 3 地区が, PV 活動が盛んな地 区と判断される。

\section{（4）PV 活動の方向性}

管理官の PV 活動に対する満足度は，活動の活発さ，専用施 設の整備, 研究会, 交流会, 管理官之の意見交換などの影響を受 けることが明らかになった。そのうち管理官との意見交換は，満 足度だけではなく，活動の活発さ，活動の有効性とも関連し，国 立公園管理のサポートが主な目的である PV 制度をより効率的 に活用するためには，国立公園行政を担当している管理官との協 議は必須であるといえる。

研究の結果から専用施設, 組織の整備が良好な地区は活動も盛 んであり，登録人数が 50 人以上の地区において活発な活動をし ていることが把握され, PV 活動の活性化のためには, 組織, 専 用施設の整備と之屯に適切な登録人数の確保が必要と考えられる。

したがって，円滑な PV 活動を推進して行くためには，管理 官の PV 活動に対するコーディネーターの役割を強化すること， 年齢制限を緩和し，活動しないPVの積極的参加をうながす方 法を検討することが必要と思われた。例えば，プログラムを作成 し，PVの都合に合わせた活動が可能にするなどの配慮を行うこ と，PVの都合が悪い時には一時的に長い期間でも活動休止を認 めるルールの設定なよ゙が考慮されるとよいではないかと思われる。

\section{参考・引用文献}

1 ）環境庁自然保護局計画課（1989）：自然・ふ れあい新時代 : 第一法規，197-210

2 ) 龟山章 (1981) : 管理員制度をかえりみて 国立公園 No.381 ・ 382，2-5

3 ）環境庁自然保護局保護管理課 (1985)：自然 保護教育活動推進事業について：かんきょ j $10(5), 60-61$

$4 ）$ 金宣希・油井正昭（2000）:日光之箱根に戈 けるパークボランティア制度の運営及び活 動に関する研究: ランドスケープ研究
63(5), 629-632

5 ) 公益信託自然保護ボランティアファンド(19 97）：公益信託自然保護ボランティアファン ド 10 年の歩み, 10-15

6 ）小島広光 (1998)：非営利組織の経営一日本 のボランティアー：北海道大学図書刊行会, 8-9

7 ）国立公園協会（1999）：自然公園の手引き: 国立公園協会, $282 \mathrm{pp}$

8 ）自然公園ボランティア活動研究会（1995） 自然公園ボランティア活動報告書, 1
9）自然ふれあい推進室（1996）：自然公園指導 員資料集， $14 \mathrm{pp}$

10）自然ふ扏あい推進室（1999）：国立公園パー クボランティア覧

11）林静一郎（1958）：利用の増大上遭難事故の 問題: 国立公園 102,2-4

12）吉澤裕之 (1987)：公益信託自然保護ボラン ティアファンドについて：国立公園 450, $14-17$

Summary: The Purpose of this study is to find the progress and characteristics of volunteer systems in the National Park. Varied problems are caused by user increase of the national park so as to settle this problem, first volunteer activity was introduced in 1957. The Growth of Volunteer is divided into 3 terms : the first term (1957 1984: introduction period), the second term (1985 1992: spread period), the third term (1993 present: growth period). In the questionnaire result, validity of PV (Park Volunteer) activity was recognized by national park managers (Park Rangers). The item which showed correlation with the satisfaction in a facilities (volunteer house, volunteer station etc.) building, a workshop, a friendship alternating current meeting and communication of park ranger and PV. 